\title{
EFFECT OF METALLURGIC PURITY OF THE 15CRMOV6-10-3 (15HGMV) STEEL ON TECHNOLOGICAL AND MECHANICAL PROPERTIES OF COLD-DEFORMED PRODUCTS
}

\begin{abstract}
The subject of the article is the analysis of the impact of electro-slag remelting - ESR on the technological and mechanical properties of the 15HGMV steel. Uniaxial compression tests were carried out with the use of a Gleeble simulator. The hardness and microstructure of deformed samples were tested. The mechanical properties were measured in a static tensile test. Significantly larger non-metallic inclusions were found in the material without ESR, as compared to the material with ESR, which may be decisive in further processing of the material in the form of thin-walled tubes with the use of cold flow forming.
\end{abstract}

Keywords: low-alloy steel, compression, microstructure, electro-slag remelting

\section{WPŁYW CZYSTOŚCI METALURGICZNEJ STALI 15CRMOV6-10-3 (15HGMV) NA WŁAŚCIWOŚCI TECHNOLOGICZNE I MECHANICZNE WYROBÓW ODKSZTAŁCANYCH NA ZIMNO}

\begin{abstract}
Przedmiotem artykułu jest analiza wpływu obróbki elektrożużlowej - EŻP na właściwości technologiczne i mechaniczne stali 15HGMV. W pracy wykonano próby ściskania jednoosiowego w symulatorze Gleeble. Badano twardość $i$ mikrostrukturę próbek odkształconych. Wykonano pomiary właściwości mechanicznych $w$ statycznej próbie rozciagania. W materiale bez EŻP $w$ porównaniu do materiału z EŻP stwierdzono występowanie znacznie większych wtraceń niemetalicznych, co może mieć decydujace znaczenie $w$ dalszym przetwarzaniu materiału $w$ postaci rur cienkościennych metoda zgniatania obrotowego na zimno.
\end{abstract}

Stowa kluczowe: stal niskostopowa, ściskanie, mikrostruktura, przetapianie elektrożużlowe

\section{INTRODUCTION}

As part of the research and development works carried out at Instytut Metalurgii Żelaza, 15HGMV steel was developed, which replaced the Bw13GNA steel used in the production of special products [1]. The technology of manufacturing semi-finished products for manufacturing final products in the form of a tube shell with a bottom with a wall thickness of approx. $1.5 \mathrm{~mm}$ was developed [2]. During industrial tests of cold flow forming, it turned out that due to too large and hard oxides occurring in the steel, there was surface damage to the products, eliminating them from further processing. As a result of these tests, an additional technological operation was introduced to improve the purity of the steel - electro-slag remelting (ESR) [3], which turned out to be indispensable for semi-finished products for cold flow forming of thin-walled tubes with a wall thickness of approx. $1.5 \mathrm{~mm}$. The studies published in [3] show that in electro-slag remelted steel, regardless of the way in which ingots are made, homogeneous and evenly distributed non-metallic inclusions of less than a dozen micrometres are formed. The prob- lem of deformability of non-metallic inclusions in steel, in hot and cold plastic working processes, has been the subject of many studies, e.g. [4]. However, there is no information on the deformability of non-metallic inclusions during cold flow forming of thin-walled products.

Considering the possibility of using cold flow forming to manufacture products of larger diameters and wall thicknesses, the analysis of the possibility of eliminating the expensive electro-slag remelting process was carried out. The aim of the study was to analyse the impact of the input material preparation method (with electro-slag processing and without electro-slag processing) on the microstructure as well as mechanical and technological properties of the 15HGMV steel.

The article presents the results of laboratory tests, on the basis of which guidelines for the material intended for flow forming tests under industrial conditions were indicated. The studies concerned in particular cold deformability of the material, including the behaviour of non-metallic inclusions. In order to verify the results of deformation tests on a laboratory scale, the material from casings flow formed under industrial conditions will be subjected to detailed studies in the field of non-metallic inclusions, microstructure and 
mechanical properties. The industrial material is currently in the preparation stage for deformation.

\section{PREPARATION OF THE MATERIAL FOR TESTING}

As part of the Institute's research work commissioned by MESKO S.A, a heat was made in an arc furnace with the use of secondary vacuum treatment and modification of non-metallic inclusions with calcium $(\mathrm{Ca})$, which was cast into ingot moulds. The chemical composition of the material is presented in Table 1. Part of the heat was subjected to the electro-slag remelting process (ESR). As a result of electro-slag remelting, the content of $\mathrm{S}, \mathrm{Si}$ and $\mathrm{Al}$ decreased. These elements form inclusions in the form of sulphides and oxides as well as inclusion compounds in the steel. Oxide inclusions are particularly unfavourable in the process of cold deformation of thin-walled products due to high hardness and limited deformability. Sulphide inclusions in the deformation process are elongated and thus contribute to the formation of anisotropy of mechanical properties. Thick-walled tubes were made from both types of material (with ESR and without ESR), which were machined and heat treated under the same conditions for cold flow forming of engine bodies with assumed final mechanical properties. Samples were taken from these materials and tested for mechanical properties and compression tests under laboratory conditions.

\section{RESULTS OF THE INVESTIGATION OF NON-METALLIC INCLUSIONS AND MICROSTRUCTURE AFTER QUENCHING AND TEMPERING}

After quenching and tempering, the 15HGMV steel is designed for cold flow forming. Therefore, in addition to mechanical properties, specific metallurgical purity is required. The number and size of inclusions, the type of inclusions and the uniformity of their distribution are of particular importance. Fig. 1 presents sample micrographs of non-metallic inclusions in the tested steel grade 15HGMV after ESR and without ESR, on longitudinal microsections (parallel to the direction of tube rolling). In the material subjected to the ESR process, the content of inclusions was very low, and the size of oxide inclusions did not exceed $5 \mu \mathrm{m}$. The material which was not subjected to ESR was characterised by a significantly higher content of inclusions. In this case, the size of oxide inclusions, sulphides and inclusion compounds reached $30 \mu \mathrm{m}$ (Fig. 1b). The microstructure of the tested materials after ESR and without ESR composed of tempered martensite and bainite did not show any significant differences (Fig. 2).

Table 1. Chemical composition of the tested material, weight \%

Tabela 1. Skład chemiczny materiału badań, \% masowe

\begin{tabular}{|l|c|c|c|c|c|c|c|c|c|c|c|c|c|}
\hline Steel grade & $\mathbf{C}$ & $\mathbf{M n}$ & $\mathbf{S i}$ & $\mathbf{F}$ & $\mathbf{S}$ & $\mathbf{C r}$ & $\mathbf{N i}$ & $\mathbf{M o}$ & $\mathbf{V}$ & $\mathbf{C u}$ & $\mathbf{A l T}$ & $\begin{array}{c}\mathbf{O} \\
\mathbf{p p m}\end{array}$ & $\begin{array}{c}\mathbf{N} \\
\mathbf{p p m}\end{array}$ \\
\hline 15HGMV & 0.17 & 0.93 & 0.11 & 0.011 & 0.005 & 1.43 & 0.09 & 0.88 & 0.23 & 0.12 & 0.039 & 31 & 45 \\
\hline 15HGMVS* & 0.17 & 0.92 & 0.05 & 0.011 & 0.002 & 1.43 & 0.09 & 0.88 & 0.23 & 0.12 & 0.019 & 20 & 72 \\
\hline
\end{tabular}

*) $\mathrm{S}$ - with electro-slag remelting
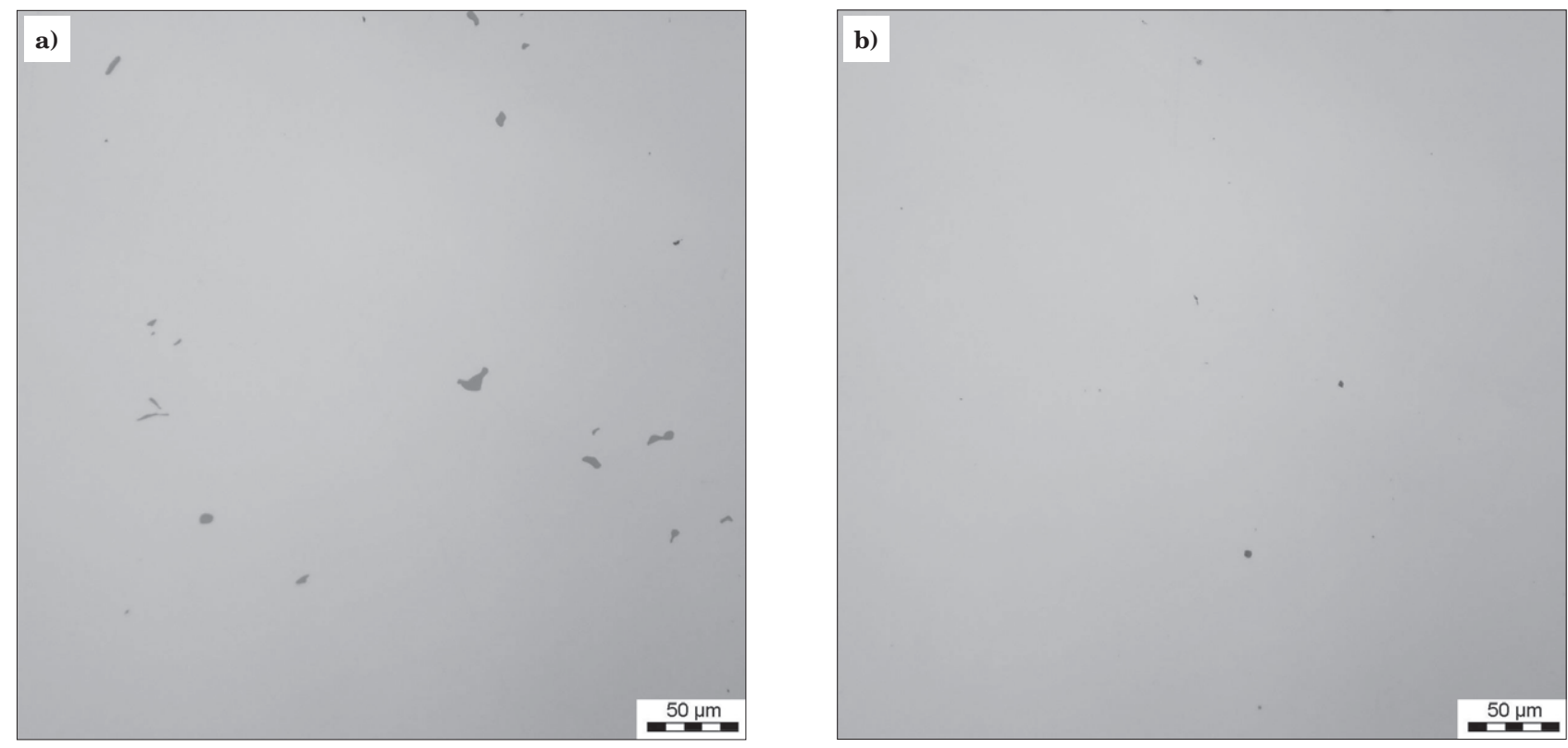

Fig. 1. Non-metallic inclusions in the 15HGMV steel (a) without ESR, (b) with ESR

Rys. 1. Wtrącenia niemetaliczne w stali 15HGMV (a) bez EŻP, (b) z Ė̇P 

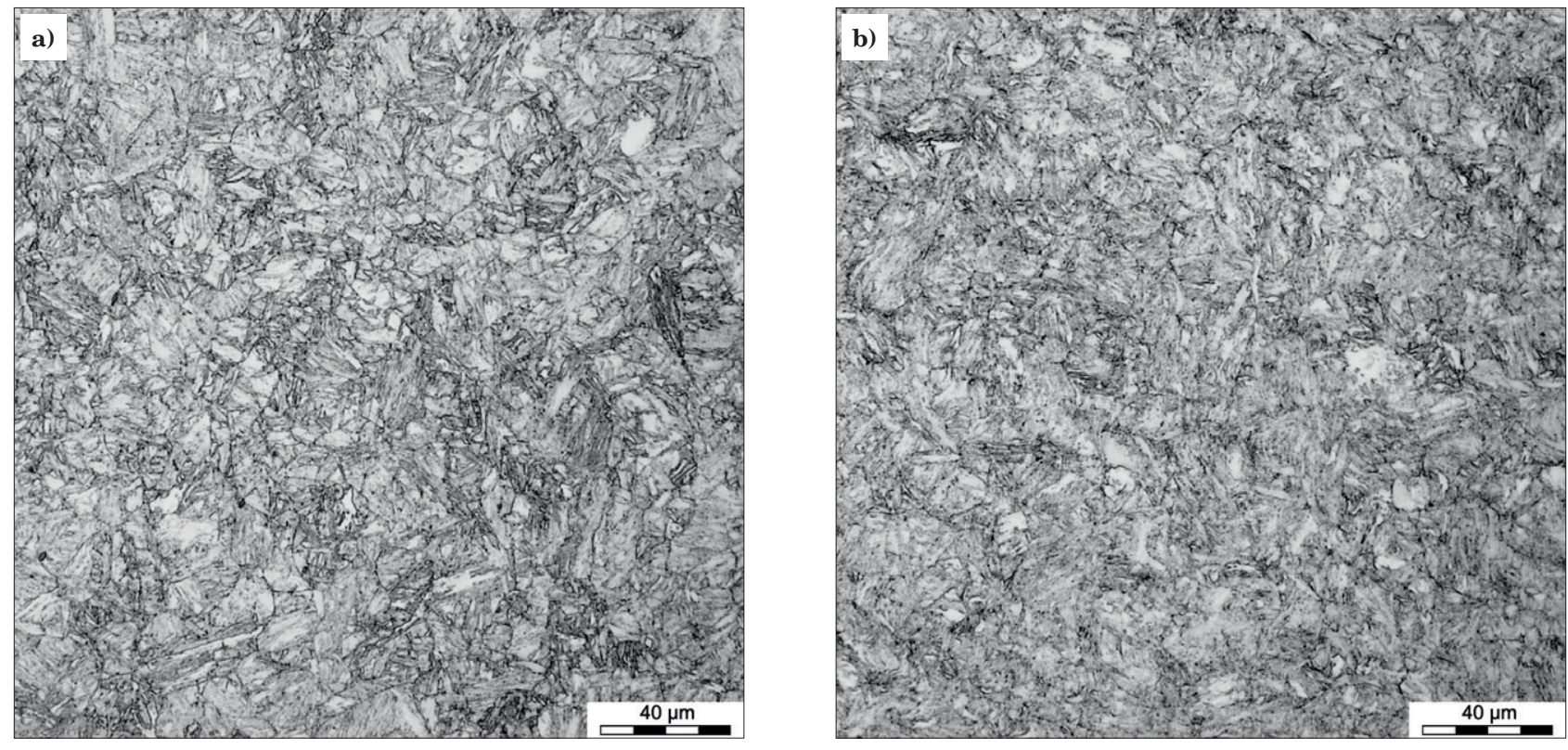

Fig. 2. Microstructure of the $15 \mathrm{HGMV}$ steel after quenching and tempering (austenitising at $970^{\circ} \mathrm{C}$ and quenching in oil and tempering at $660^{\circ} \mathrm{C}$ ) (a) without ESR, (b) with ESR

Rys. 2. Mikrostruktura stali 15HGMV po ulepszaniu cieplnym (austenityzowanie $w 970^{\circ} \mathrm{C}$ i hartowanie w oleju oraz odpuszezanie w temperaturze $\left.660^{\circ} \mathrm{C}\right)($ a) bez EŻP, (b) z Ė̇P

\section{RESULTS OF THE INVESTIGATION OF MECHANICAL PROPERTIES AFTER QUENCHING AND TEMPERING}

The tests of mechanical properties were carried out using $\phi 10 \times \mathrm{M} 16 \mathrm{~mm}$ round strength samples cut from tubes rolled from the material after ESR and without ESR. The samples were taken longitudinally to the rolling direction of the tubes. Hardening of strength samples and their tempering at temperatures of $680^{\circ} \mathrm{C}$, $660^{\circ} \mathrm{C}$ and $640^{\circ} \mathrm{C}$ were carried out. Table 2 presents the results of the measurement of properties in a static tensile test and hardness measurement. Based on the obtained measurement results, it was found that the use of the ESR process did not affect the strength and elongation or hardness of semi-finished products for flow forming.

\section{RESULTS OF COLD DEFORMABILITY TESTS WITH A GLEEBLE SIMULATOR}

In order to determine the effect of the method of material preparation on the behaviour of steel during cold deformation, tests were carried out with the use of a Gleeble simulator. The used material was subjected to quenching and tempering. $\phi 5 \times 7 \mathrm{~mm}$ cylindrical samples were uniaxially compressed with a total deformation of up to 1.2 with a strain rate of 1,10 and $50 \mathrm{~s}^{-1}$. The samples were not cooled during the experiments. On the side of the deformed samples, there was an increase in temperature to $110-130^{\circ} \mathrm{C}$ for the strain rate of $1 \mathrm{~s}^{-1}$ and $200-240^{\circ} \mathrm{C}$ and $230-255^{\circ} \mathrm{C}$, respectively for the rates of 10 and $50 \mathrm{~s}^{-1}$. The temperature increase on the surface of the sample to the above values indicates that the temperature inside the sample reached much higher values. Fig. 3 presents material compression curves after ESR and without ESR deformed at the rates of 1,10 and $50 \mathrm{~s}^{-1}$. A significant strengthening of the material (up to $1700 \mathrm{MPa}$ ) occurred for compression

Table 2. Mechanical properties and hardness of semi-finished products for cold flow formed casings (after quenching and tempering, austenitising at $970^{\circ} \mathrm{C}$ with oil cooling; $\mathrm{Tt}$ - tempering temperature)

Tabela 2. Właściwości mechaniczne i twardość półwyrobów do wytwarzania korpusów metoda zgniatania obrotowego na zimno (po ulepszaniu cieplnym, austenityzowanie w $970^{\circ} \mathrm{C}$ z chłodzeniem $w$ oleju; $T o$ - temperatura odpuszczania)

\begin{tabular}{|c|c|c|c|c|}
\hline \multirow{2}{*}{$\begin{array}{c}\text { Material } \\
\left(\boldsymbol{T} \boldsymbol{t},{ }^{\circ} \mathbf{C}\right)\end{array}$} & $\begin{array}{c}\text { Apparent yield strength } \\
\boldsymbol{R}_{\mathbf{p} \mathbf{2}, \mathbf{2}}\end{array}$ & $\begin{array}{c}\text { Tensile strength } \\
\boldsymbol{R}_{\mathbf{m}}\end{array}$ & $\begin{array}{c}\text { Total elongation } \\
\boldsymbol{A}\end{array}$ & Hardness \\
\cline { 2 - 5 } & $\mathbf{M P a}$ & $\mathbf{M P a}$ & $\boldsymbol{H}$ & $\mathbf{H V}$ \\
\hline 680/ESR & 1003 & 1047 & 18.1 & 343 \\
\hline $680 / \mathrm{W} / \mathrm{O}$ & 998 & 1044 & 17.9 & 343 \\
\hline $660 / \mathrm{ESR}$ & 1070 & 1126 & 18.0 & 362 \\
\hline $660 / \mathrm{W} / \mathrm{O}$ & 1079 & 1131 & 17.1 & 364 \\
\hline $640 / \mathrm{ESR}$ & 1131 & 1208 & 17.2 & 389 \\
\hline $640 / \mathrm{W} / \mathrm{O}$ & 1107 & 1211 & 17.2 & 389 \\
\hline
\end{tabular}


tests with a strain rate of $1 \mathrm{~s}^{-1}$. There was no increase in stress depending on the type of material (ESR and without ESR). For higher strain rates, e.g. due to the increase of the sample temperature and the location of the deformation, there was a decrease in stress and, as a result, a smaller strengthening as compared to the samples compressed at the speed of $1 \mathrm{~s}^{-1}$. It should be noted that during uniaxial compression, the tendency to deformation localisation increases with the increase
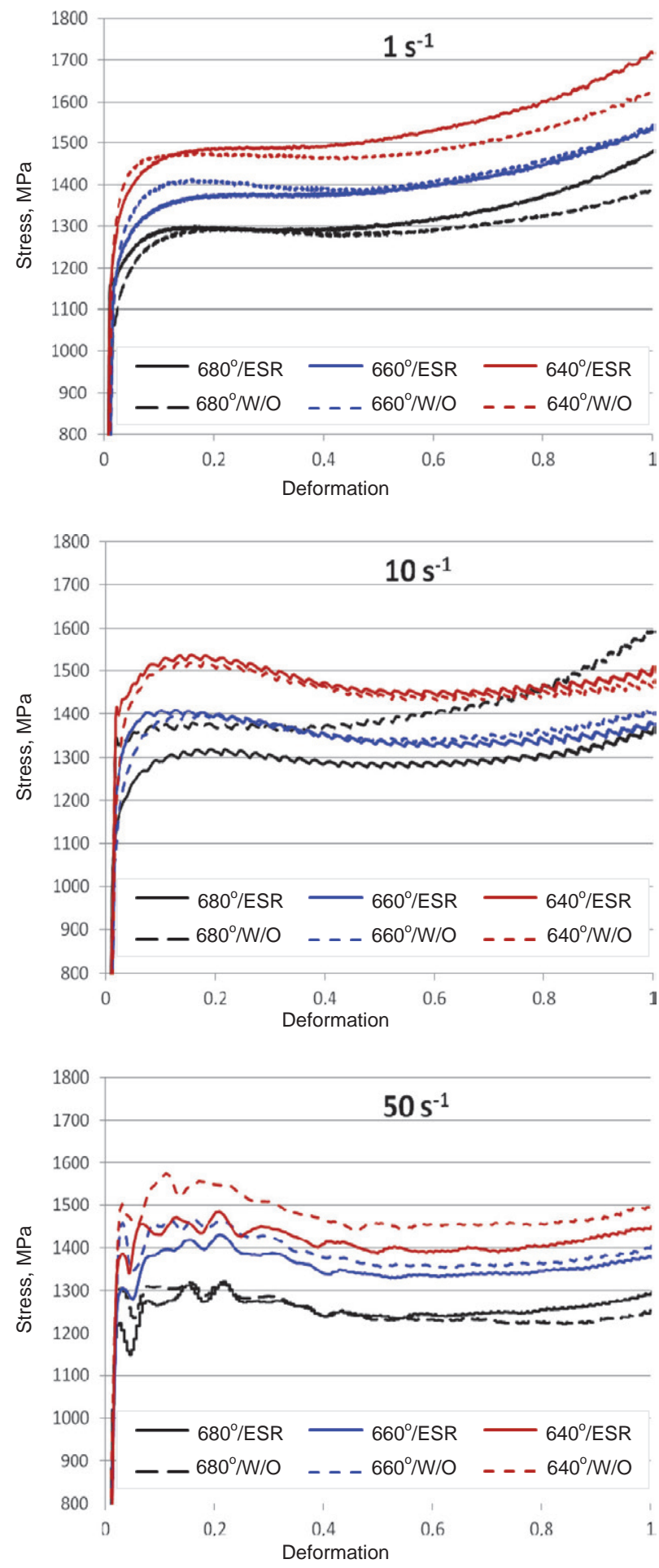

Fig. 3. Compression curves of the 15GHMV steel deformed at ambient temperature at the following strain rates: $1 \mathrm{~s}^{-1}$; $10 \mathrm{~s}^{-1}$ and $50 \mathrm{~s}^{-1}$

Rys. 3. Krzywe ściskania stali 15HGMV odkształcanej w temperaturze otoczenia z prędkościami: $1 \mathrm{~s}^{-1} ; 10 \mathrm{~s}^{-1}$ i $50 \mathrm{~s}^{-1}$ in strain rate. After exceeding the deformation value of about 0.5 , the effects of strain hardening begin to dominate over the effects of the decrease in stress associated with the increase in temperature. Structural changes regarding the above mechanisms are difficult to observe and require the use of advanced research techniques, e.g. electron microscopy.

\section{RESULTS OF HARDNESS MEASUREMENT AFTER QUENCHING AND TEMPERING AND COLD DEFORMATION}

The value of strain hardening was determined on the basis of hardness measurement on the cross-section of the sample axis (in the middle of the height). HV10 hardness was measured after cold-upsetting in a Gleeble simulator. Fig. 4 presents the results of measurement for the strain rate of $10 \mathrm{~s}^{-1}$. A significant decrease in hardness was observed with an increase in the tempering temperature from $660^{\circ} \mathrm{C}$ to $680^{\circ} \mathrm{C}$. The preparation of the material (with and without ESR) had no effect on the hardness of the deformed material. Fig. 5 presents a list of hardness measurement results for samples deformed in relation to the material after quenching and tempering. The average hardness was

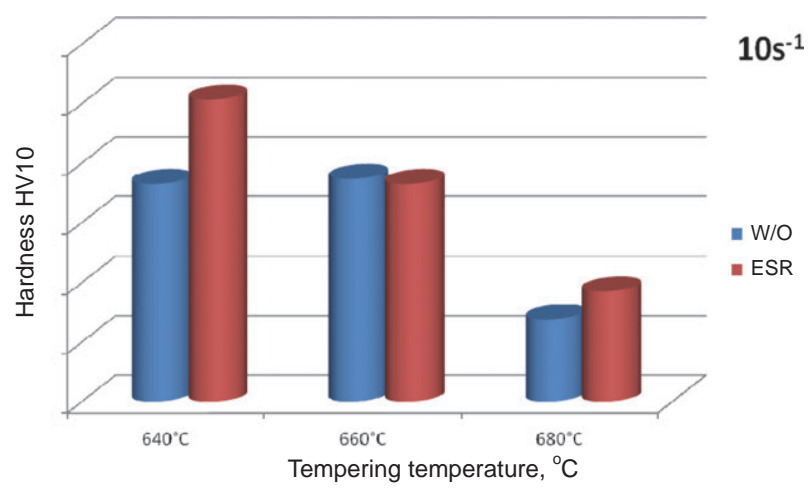

Fig. 4. Hardness of specimens subjected to uniaxial compression in a Gleeble simulator

Rys. 4. Twardość próbek poddanych jednoosiowemu ściskaniu w symulatorze Gleeble

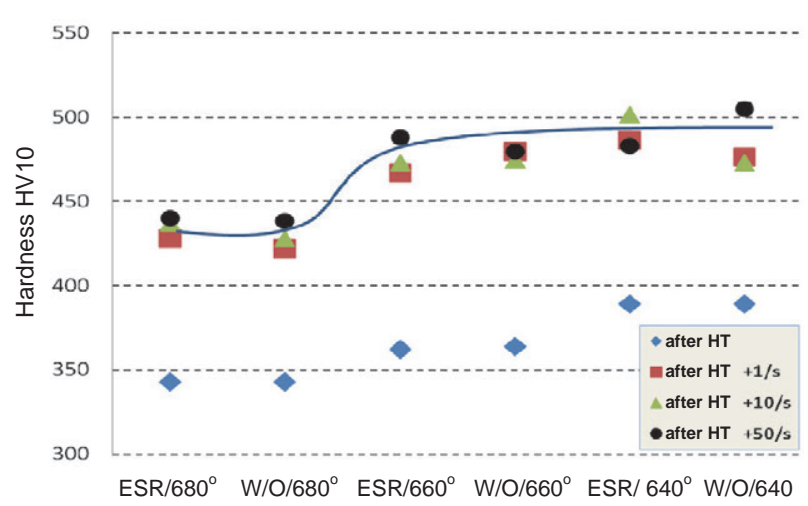

Fig. 5. Hardness changes due to uniaxial cold compression carried out with a Gleeble simulator at the strain rates of 1,10 and $50 \mathrm{~s}^{-1}$

Rys. 5. Zmiany twardości w wyniku ściskania jednoosiowego na zimno w symulatorze Gleeble z prędkościami odkształcenia 1,10 i $50 \mathrm{~s}^{-1}$ 
increased by approx. 50-60 $\mathrm{HV}$ for the tempering temperature of $680^{\circ} \mathrm{C}$, and $660^{\circ} \mathrm{C}$ and $640^{\circ} \mathrm{C}$ for the strain rate range of $1-50 \mathrm{~s}^{-1}$. There was no clear difference in the hardness gain (quantitative strengthening effect) between the tested material variants (with ESR and without ESR).

\section{RESULTS OF THE INVESTIGATION OF NON-METALLIC INCLUSIONS AND MICROSTRUCTURE AFTER QUENCHING AND TEMPERING AND COLD DEFORMATION}

The investigation of the behaviour of non-metallic inclusions during cold deformation with the use of the uniaxial compression method was performed by means of a light microscope. During compression, a multiaxial state of stress arises in the sample and the material is subjected to, among others, tensile stress in the direction perpendicular to the compression direction. Fig. 6 presents sample images of non-metallic inclusions in a sample from the ESR material after compression at the speed of 1,10 and $50 \mathrm{~s}^{-1}$. It was found that the state was similar to the material before deformation in terms of content and shape of inclusions. There were occasional undeformed oxides and/or slightly elongated sulphur oxides of less than $5 \mu \mathrm{m}$ in size. Strongly elongated manganese sulphides and/or (Fe, Mn)S and undeformed primary oxides of the size of several $\mu \mathrm{m}$ were found in the material without ESR (Fig. 7). Inclusions in the form of hard, non-deformable particles over $10 \mu \mathrm{m}$ may be sources of stress concentration during flow forming. In addition, hard oxides may prevent the thin-walled casings from being formed by cutting the material during simultaneous feed, rotation and plastic deformation in the process of flow forming. A quantitative analysis of non-metallic inclusions in the materials under investigation will be performed after industrial tests.

The microstructure of the tested material variants was similar in terms of morphology and uniformity (Fig. 8 and 9). It consisted of significantly elongated bainitic ferrite laths and martensite laths. In the examination of the material after deformation, no microcracks or voids were found, in particular around non-metallic inclusions in both types of materials.

\section{SUMMARY}

The article presents the results of laboratory tests of cold deformability of the 15CrMoV6-10-3 (15HGMV) steel ESR and without ESR. Examination of non-metallic inclusions, microstructure, and hardness measurement were carried out and flow curves for samples compressed with deformation velocities in the range of 1-50 $\mathrm{s}^{-1}$ were determined.

The tested material variants did not show significant differences in the type of microstructure, hardness and properties, including the value of strain hardening under uniaxial compression. The only significant difference concerned the form and size of non-metallic inclusions in the materials after deformation. The difficult-to-deform hard particles of oxides of the size
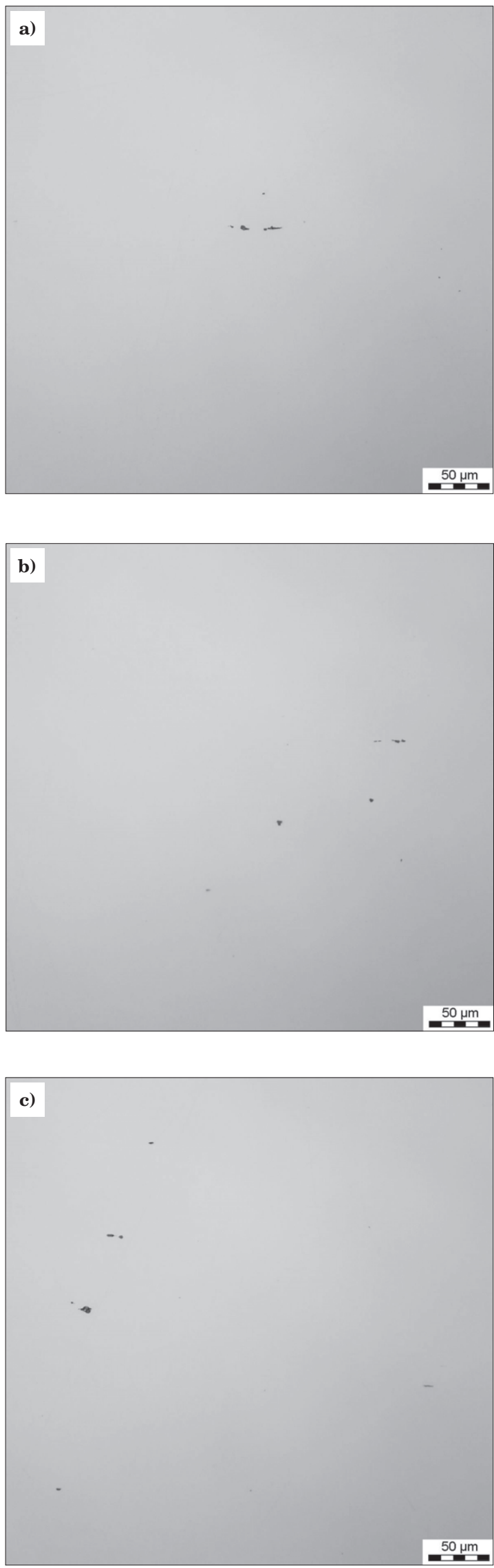

Fig. 6. Non-metallic inclusions after cold deformation in the ESR material. Tempering temperature of $660^{\circ} \mathrm{C}$. Strain rate: (a) $1 \mathrm{~s}^{-1}$, (b) $10 \mathrm{~s}^{-1}$, (c) $50 \mathrm{~s}^{-1}$

Rys. 6. Wtrącenia niemetaliczne po odkształceniu na zimno $w$ materiale EŻP. Temperatura odpuszczania $660^{\circ} \mathrm{C}$. Prędkość odkształcenia: (a) $1 \mathrm{~s}^{-1}$, (b) $10 \mathrm{~s}^{-1}$, (c) $50 \mathrm{~s}^{-1}$ 

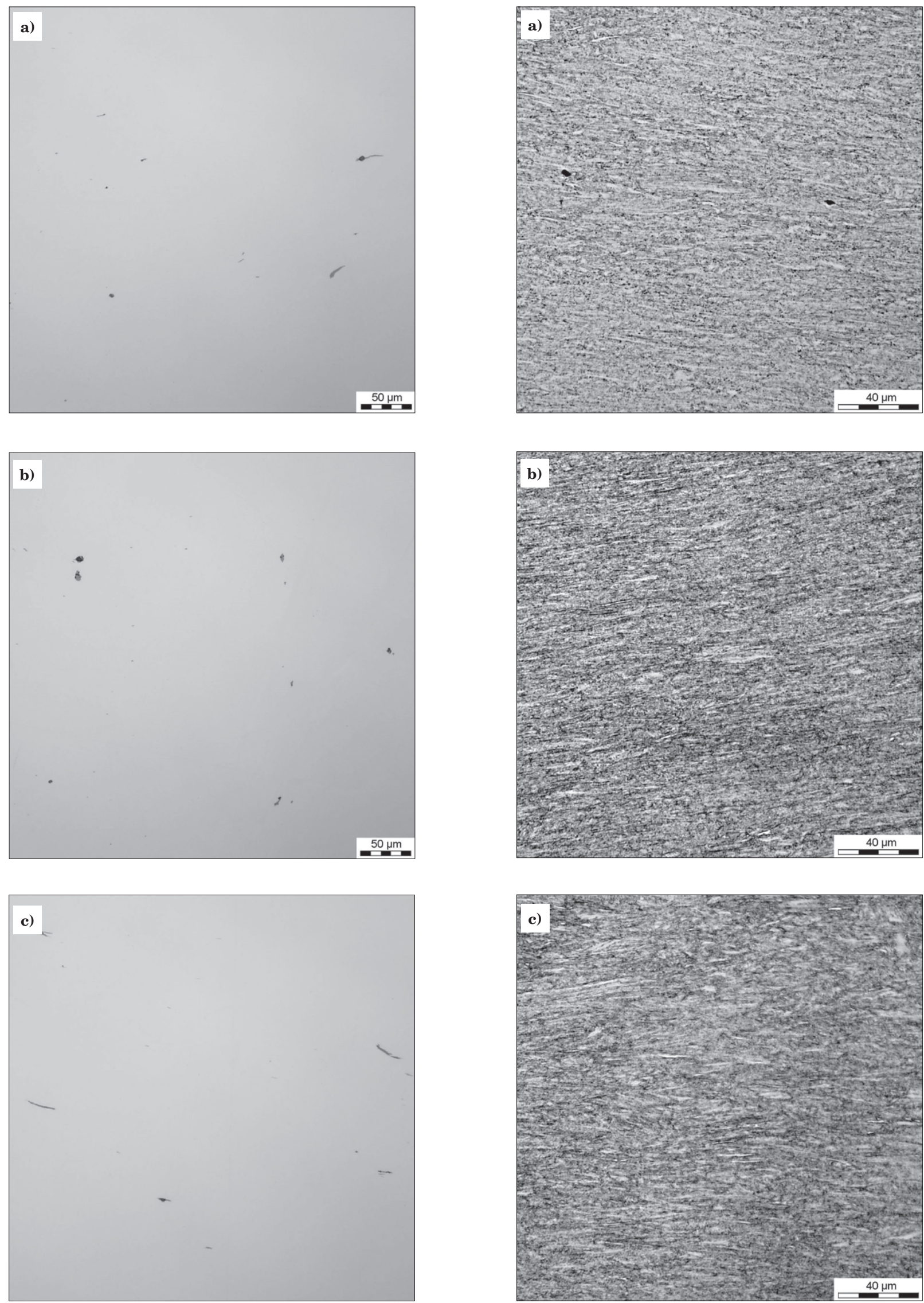

Fig. 7. Non-metallic inclusions in the material without ESR after cold deformation. Tempering temperature of $660^{\circ} \mathrm{C}$. Strain rate: (a) $1 \mathrm{~s}^{-1}$, (b) $10 \mathrm{~s}^{-1}$, (c) $50 \mathrm{~s}^{-1}$

Rys. 7. Wtracenia niemetaliczne $w$ materiale bez EŻP po odkształceniu na zimno. Temperatura odpuszczania $660^{\circ} \mathrm{C}$. Prędkość odkształcenia: (a) $1 \mathrm{~s}^{-1}$, (b) $10 \mathrm{~s}^{-1}$, (c) $50 \mathrm{~s}^{-1}$

Fig. 8. Microstructure of samples after cold deformation. ESR material, tempering temperature $660^{\circ} \mathrm{C}$. Strain rate: (a) $1 \mathrm{~s}^{-1}$, (b) $10 \mathrm{~s}^{-1}$, (c) $50 \mathrm{~s}^{-1}$

Rys. 8. Mikrostruktura próbek po odkształceniu na zimno. Materiał EŻP, temperatura odpuszezania $660^{\circ} \mathrm{C}$. Prędkość odkształcenia: (a) $1 \mathrm{~s}^{-1}$, (b ) $10 \mathrm{~s}^{-1}$, (c) $50 \mathrm{~s}^{-1}$ 

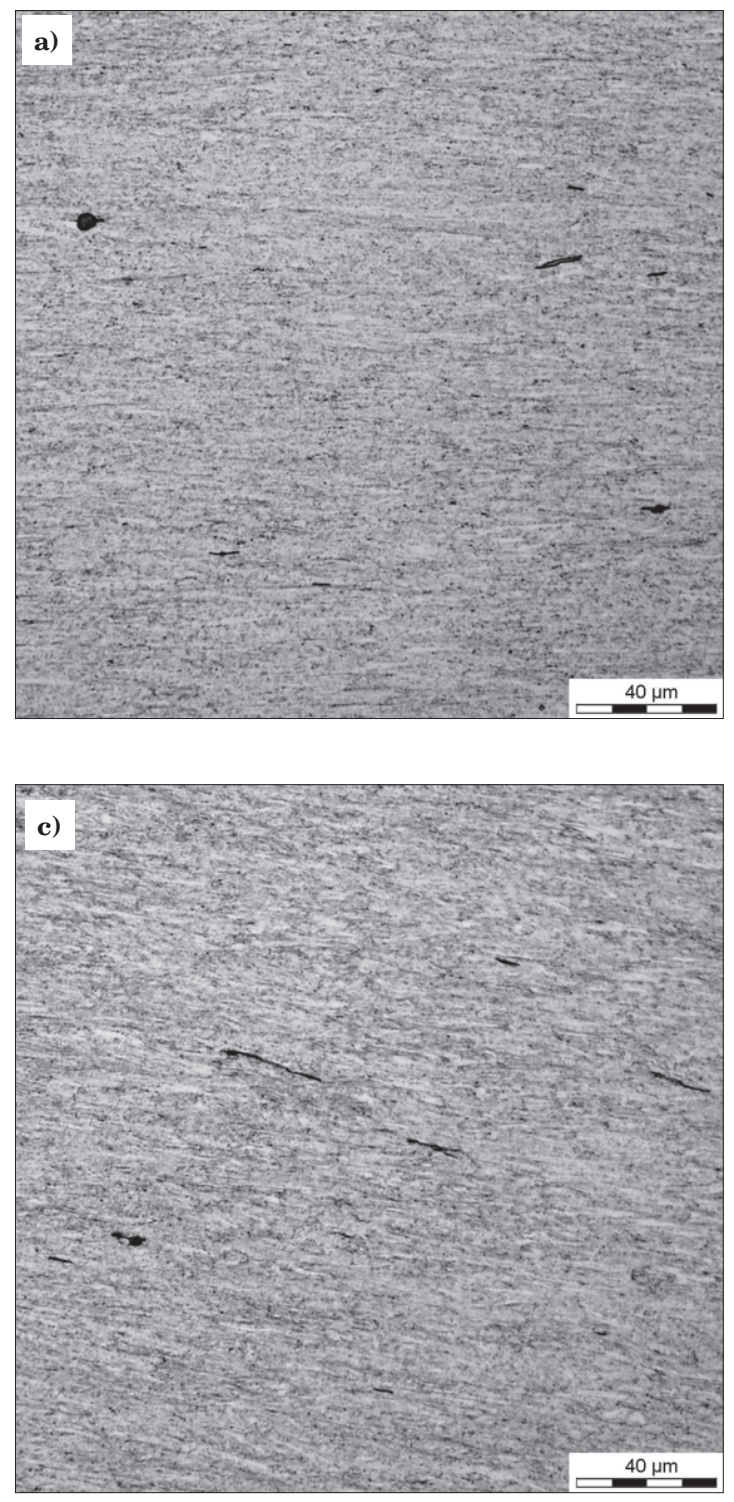

of several $\mu \mathrm{m}$, which are present in the material without ESR, can be an obstacle to obtaining thin-walled casings of the required quality. Inclusions in the form of hard particles of critical size constitute sources of stress concentration and additionally may prevent the production of thin-walled casings by cutting the material during simultaneous feed, rotation and plastic deformation during flow forming. The state of stress and strain in the uniaxial compression test only partially corresponds to the multi-axial state during flow forming. For this reason, it is necessary to verify the deformability of materials in industrial flow forming tests.

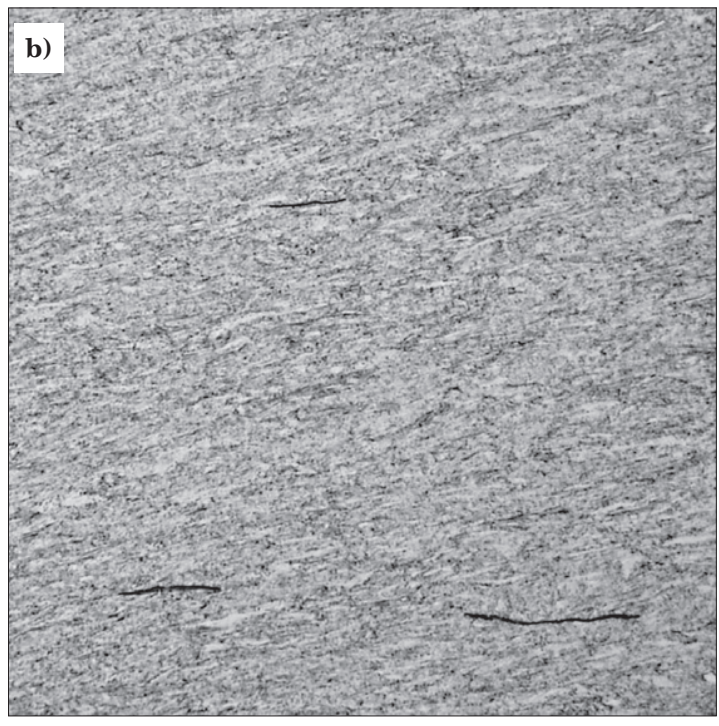

Fig. 9. Microstructure of samples after cold deformation. Material without ESR, tempering temperature $660^{\circ} \mathrm{C}$. Strain rate: (a) $1 \mathrm{~s}^{-1}$, (b) $10 \mathrm{~s}^{-1}$, (c) $50 \mathrm{~s}^{-1}$

Fig. 9. Microstructure of cold deformed specimens. Material not subjected to electroslag remelting, tempering temperature $660^{\circ} \mathrm{C}$. Strain rate: (a) $1 \mathrm{~s}^{-1}$, (b) $10 \mathrm{~s}^{-1}$, (c ) $50 \mathrm{~s}^{-1}$

Further studies assume the production of experimental engine bodies with the use of cold flow forming from the two types of materials tested. Based on the results of these tests and material tests, requirements for the production of semi-finished products for the flow forming of engine bodies with larger diameters than currently performed will be specified.

The article contains part of the results of the work funded by NCRD under the project "Auxiliary engines for solid fuel for carried rockets using liquid fuel" carried out in accordance with Agreement No. DOB-BIO8/06/01/2016.

\section{REFERENCES}

[1] J. Stępień, J. Paduch, J. Materniak, A. Starczewska. Struktura i właściwości mechaniczne stali 15HGMV na korpusy silników rakietowych. In: III Międzynarodowa Konferencja Uzbrojeniowa. Waplewo 2000.

[2]Z. Kaczmarek. Wybrane problemy badawcze związane z wykonaniem rakiety niekierowanej „Feniks”. In: AMUNICJA 2002 Badania i rozwój systemu BM-21 oraz nowoczesnej amunicji. Kołobrzeg 2002, p. 109-124.
[3] J. Stępień. Wpływ technologii wytwarzania na właściwości strukturalne i mechaniczne stali 15JGMV po zgniataniu obrotowym na zimno. In: AMUNICJA 2011 Perspektywy rozwoju krajowej produkcji napędów rakietowych oraz amunicji strzeleckiej $i$ artyleryjskiej. Kołobrzeg 2011, No. 2, p. 131-176.

[4] S. Pytel. Wtracenia niemetaliczne $w$ stopach żelaza. Monografia 65. Kraków: Wydawnictwo Politechniki Krakowskiej, 1988. 